\title{
Entrepreneurial Orientation: Ability to Create Innovations during the Covid-19 Pandemic
}

\author{
Wahju Hidajat ${ }^{1}$, Handoyo Djoko Waloejo $^{2}$, Reni Shinta Dewi ${ }^{3}$ \\ \{renishinta@yahoo.co.id ${ }^{3}$ \} \\ Universitas Diponegoro, Indonesia ${ }^{1,2,3}$
}

\begin{abstract}
The emergence of the Covid-19 pandemic has had a tremendous impact, especially for the business industry. One of the industries that was affected was the Batik SMEs. Even at the beginning of the outbreak, the operation of the Batik SMEs had stopped. Innovation is a strategy that plays an important role in dealing with these conditions. However, SMEs have difficulties due to limited resources. Entrepreneurial orientation is needed because it is an ability that encourages innovation. The research was conducted at the largest batik industry in Central Java-Laweyan. A sample of 198 respondents from 200 questionnaires distributed for that respond rate is $90 \%$. Regression analysis is used using SPSS. The results show that the dimensions of innovativeness, risk taking, and competitive aggressiveness have a significant effect on innovation. Meanwhile, proactive and autonomy have no significant effect on innovation. This finding differs from previous studies, especially for the proactive and autonomy dimensions. This is considered reasonable given the unpredictable pandemic conditions and comes suddenly so that the Batik SME's does not have the ability to respond quickly to the conditions that occur. Further research is necessary to include the flexibility strategy of SMEs because this strategy is considered the most suitable with current conditions.
\end{abstract}

Keywords: Entrepreneurial Orientation, Innovation, SMEs, Pandemic Covid-19

\section{Introduction}

The impact of the current Covid-19 pandemic is being felt by many people in various countries around the world. According to Worldometers, the COVID-19 Pandemic as of August 11,2020, recorded 20,254,685 positive cases of corona with 738,930 deaths. Cases in Indonesia until August have reached 127,083 positive cases with details of 5,765 deaths and 82,236 people recovered [1]. The increase in the Covid-19 Pandemic will affect global economic growth. There are three major impacts due to the Covid-19 Pandemic on the economy in Indonesia. First, the decline in household consumption to $60 \%$ of the Indonesian economy. Second, the Covid-19 Pandemic has caused prolonged uncertainty resulting in weakening investment which can cause a business to stop. Furthermore, the last impact is that commodity prices have dropped and export activities to various countries have also stopped [2].

The four sectors most affected by the Covid-19 Pandemic are households, MSMEs, corporations, and the financial sector. It is predicted that economic growth will experience unstable shocks. MSMEs themselves experienced a significant decline of $70 \%$ due to the Covid-19 Pandemic [3]. One of the affected MSMEs is the Batik industry. This industry stopped operating at the start of the pandemic. The emergence of this epidemic has 
encouraged Batik MSMEs to create innovation. Innovation is an important strategy, especially when there are changes. Even so, Schumpeter [4] stated that MSMEs have greater difficulties than large companies to innovate because they have limited access to resources [5]. These limitations include the difficulty of being able to adapt to the environment, lack of ability to read business opportunities, lack of innovation in anticipating various environmental challenges. On the other hand, in the internal operations of MSMEs, they are weak in managerial abilities, skills, promotions and lack of capital. The form of application of entrepreneurial attitudes can be indicated by entrepreneurial orientation with an indication of innovation ability, proactivity, and ability to take risks [6]. Lumpkin and Dess [7] stated that companies that have a strong entrepreneurial orientation will be more willing to take risks, and not only stick to the company's past strategies. This is because entrepreneurial orientation has five aspects, namely autonomy, innovation, taking risks, being proactive, and aggressive. Entrepreneurial orientation is considered capable of collaborating with innovation in creating unique opportunities for the survival of a product and industrial growth. Companies that have a strong entrepreneurial orientation will have the ability to innovate better than other companies that do not have an entrepreneurial orientation. Baker and Sinkula [8] stated that entrepreneurial orientation has a positive and significant effect on product innovation. For this reason, the main contribution of this research is to explore entrepreneurial orientation, especially in creating innovation during the Covid-19 Pandemic.

\section{Literatur Review}

\subsection{The Influence of Entrepreneurial Orientation on Innovation}

Entrepreneurial orientation is an important factor for innovation [9]. Entrepreneurial orientation refers to trends, processes and behaviors that direct companies to enter new or existing markets with existing or new products [7].

According to Miller, a company with an entrepreneurial orientation is one that is involved in market innovation, doing a rather risky business, first doing it with proactive innovation, and beating competitors [6]. In small companies, to become more innovative and profitable, flexible structures that allow it to respond quickly to changes in a competitive environment is to constantly seek new ways to be more flexible and the adoption of an entrepreneurial orientation will increase the ability to be innovative and more competitive [10].

Companies will gain many benefits by adopting an entrepreneurial orientation [11], this is because entrepreneurial orientation is considered the first step in understanding innovation [9][10] and plays a key role in the company's competitive advantage [7]. Based on previous theory and empirical studies, the hypotheses built from this relationship are:

$\mathrm{H} 1$ = innovativeness has a significant effect on innovation.

$\mathrm{H} 2$ = risk taking has a significant effect on innovation.

$\mathrm{H} 3$ = pro-activeness has a significant effect on innovation.

$\mathrm{H} 4=$ competitive aggressiveness has a significant effect on innovation.

H5 = autonomy has a significant effect on innovation. 


\section{Material and Method}

\subsection{Measures}

Entrepreneurial orientation (EO) is measured using 5 indicators that adopt research conducted by Lumpkin and Dess [7], namely: innovativeness, risk taking, proactiveness, competitive aggressiveness, autonomy with a 5-point Likert scale. The results of validity and reliability show all dimensions are valid and reliable.

Innovation. The measurement uses a 5-point Likert scale by adopting 4 indicators in the study of Kalkan, Bozkurt and Arman [12], namely product, process, marketing and organizational innovation. The results of validity and reliability tests show all indicators are valid and reliable.

\subsection{Data Analysis}

The research was conducted at the largest batik industrial center in Laweyan-Solo, Central Java, Indonesia. Data were collected for 6 (two) weeks by visiting respondents after getting time to meet. In addition, the use of the batik community (Paguyuban/social capital) was carried out in order to obtain a high response rate [13]. A total of 200 questionnaires were distributed. From a variety of attempts, including formal and informal contacts, we received 198 complete questionnaires across selected regions representing a 90\% response rate. We found that the sample structure matched the population with the goodness of fit test [14]. The data collected from the questionnaire were analyzed using the Statistical Package for Social Sciences (SPSS) for statistical analysis. Regression analysis is used to examine the effect of the independent variable on the dependent variable.

\section{Result and Discussion}

Demographic information shows that the majority of respondents are male $(60.6 \%)$, with ages ranging from $40-50$ years $(52.9 \%)$ and only $3 \%$ of respondents are under 30 years old. Most of the Batik industry has been running for $4-13$ years $(66.7 \%)$, with the education of most respondents at the secondary school level, namely $50.5 \%$. In the Batik industry, the number of workers used is usually in the range of $11-20$ craftsmen (45\%). The number of workers in the Batik industry is usually a combination of permanent and piece workers, with a composition of $40 \%-60 \%$ or $50 \%-50 \%$.

The correlation shows that the dimensions of pro-activeness, and autonomy have a strong relationship with innovation $(r=0.707, r=0.708, \rho=0.00)$, while moderate correlation can be seen in the relationship pathway with risk taking, competitive aggressiveness and innovativeness $(r=0.556, r=0.463 r=0.518$ with a value of $\rho=0.00)$. Proactive and Innovativeness have a determinant value $(\mathrm{M}=3.99, \mathrm{M}=3.91)$ in explaining innovation.

Table 1. Mean, Standard Deviation, Correlation

\begin{tabular}{|c|c|c|c|c|c|c|c|}
\hline Var & $\mathbf{M}$ & SD & $\begin{array}{l}\text { Innova- } \\
\text { tiveness }\end{array}$ & $\begin{array}{c}\text { Risk- } \\
\text { Taking }\end{array}$ & $\begin{array}{c}\text { Pro- } \\
\text { active }\end{array}$ & $\begin{array}{c}\text { Comp. } \\
\text { Agresiveness }\end{array}$ & $\begin{array}{l}\text { Auto- Inno- } \\
\text { nomy vation }\end{array}$ \\
\hline Innova-iveness & 3.91 & 0.56 & 1 & & & & \\
\hline Risk Taking & 3.54 & 0.67 & $.421^{* *}$ & 1 & & & \\
\hline Pro-active & 3.99 & 0.65 & $.350^{* *}$ & $.551^{* *}$ & 1 & & \\
\hline
\end{tabular}




\begin{tabular}{|c|c|c|c|c|c|c|c|c|}
\hline Comp. Agresiveness & 3.52 & 0.70 & $.414^{* *}$ & $.519^{* *}$ & $.407^{* *}$ & 1 & & \\
\hline Autonomy & 3.77 & 0.70 & $.414^{* *}$ & $.428^{* *}$ & $.555^{* *}$ & $.474^{* *}$ & 1 & \\
\hline Innovation & 3.06 & 0.41 & $.518 * *$ & $.556^{* *}$ & $.707 * *$ & $.463^{* *}$ & $.708 * *$ & 1 \\
\hline
\end{tabular}

Table 2. Regression Analysis

\begin{tabular}{|c|c|c|c|c|}
\hline Variable & $\beta$ & $\mathbf{t}$ & Sig. & Summary \\
\hline Innovati-veness & 0.159 & 3,355 & 0.001 & Positif and Significant \\
\hline Risk Taking & 0.136 & 3,352 & 0.001 & Positif and Significant \\
\hline Proactive & 0.072 & 1,757 & 0.8 & Positif and Unsignificant \\
\hline Competit-ve Agresive-ness & 0.156 & 4,247 & 0.00 & Positif and Significant \\
\hline Autonomy & 0.061 & 1,611 & 0.109 & Positif and Unsignificant \\
\hline
\end{tabular}

The results in table 2 show that the value of $\rho$ innovativeness $(\rho=0.001)$, risk taking ( $\rho=$ $0.001)$ and innovation $(\rho=0.000)$ are below the value of the expected significance level (0.05), therefore supporting H.1, H.2 and H.4. While in the path of proactive and autonomy influence did not have a significant effect on innovation $(\rho=0.8$ and $\rho=0.109)$. This finding differs from previous studies, especially for the proactive and autonomy dimensions. The regression results show that Innovativeness has a positive and significant effect on innovation. Schumpeter [4] describes the economic process as "creative destruction", where wealth is created when the existing market structure is entered by new products or services that shift the resources of existing companies and cause the new companies to grow. The key to this cycle of activity is entrepreneurship: the introduction of innovative competitive "new combinations" promotes the dynamic evolution of economies [4]. Thus "innovative nature" becomes an important factor used to characterize entrepreneurship. Risk Taking has a positive and significant effect on innovation. Cantillon [15], who was the first to formally use the term entrepreneurship, argued that the main factor separating employers from hired employees was uncertainty and entrepreneurial risk. Therefore, the concept of risk taking is a term often used to describe entrepreneurship. Competitive aggressiveness has a positive and significant effect on innovation. Competitive aggressiveness refers to the tendency of a company to directly challenge its competitors to enter or increase its position by outperforming industrial competitors in the market. Competitive aggressiveness also reflects the desire to be modern and not rely on traditional methods to compete. Examples of modern competitive aggressiveness for newcomers are, analyzing and targeting competitor weaknesses [16] and focusing on high value-added products coupled with monitoring unnecessary expenditure [17]. Likewise, Porter [18] recommends three approaches for pursuing existing firms aggressively namely doing things differently (reconfiguring), changing the context (redefining the product or service and its channels or market scope), and spending more money than the industry leader.

Proactive (activeness) has no significant effect on innovation. Proactive refers to how a company deals with the process of entering new market opportunities. Companies act by taking the initiative and acting on an opportunity to "shape the environment" in the market, that is, to influence trends and create demand. Until recently proactive traits were used to describe the companies that innovate the fastest and the first to introduce new products or services. This was stated by Miller and Friesen [19] about entrepreneurial companies as companies that "produce proactive innovation for the first time".

Autonomy has no significant effect on innovation. The concept of autonomy is a key dimension of entrepreneurial orientation. Autonomy refers to the independent action of an 
individual or organization in generating an idea or vision and bringing it to completion. In general, this means the ability and willingness to direct oneself in pursuit of opportunities. Hart [20] suggests an integrative framework including a generative mode, in which strategy making occurs from the entrepreneurial activities of organizational members that produce ideas which are then passed on to higher levels of management. Hart's opinion is supported by Bourgeois [21] who describe the Crescive model, which is a strategy initiated in the organization through individual entrepreneurship. This model suggests that the impetus for new ventures often occurs at a lower level within an organization [22] and reflects the autonomy to organizational members that may be found in internal corporate business settings. In both cases, freedom to act independently is an important dimension of entrepreneurial orientation.

\section{Conclusion}

The findings of this study supported the results of research conducted by $\mathrm{Wu}$, Chang, and Chen [9] that entrepreneurial orientation encourages the development of innovation. Entrepreneurial orientation, with the characteristics of innovation, risk-taking, pro-activeness, competitive aggressiveness, and autonomy [6][7], is the key to creating a higher level of innovation [23][24]. Organizations with a high entrepreneurial orientation can continue to identify and take advantage of opportunities that arise [25]. Entrepreneurial orientation stimulates the innovative potential and organizational creativity, creates a proactive attitude towards innovation [8]. The limitation of this research is using a cross-sectional method that didn't saw the development of entrepreneurial orientation in a comprehensive. For future studies is necessary to include the flexibility strategy of SMEs because this strategy is considered the most suitable with current conditions.

\section{References}

[1] Worldometers, “Covid-19 Coronavirus Pandemic," Worldometers, 2020. [Online]. Available: https://www.worldometers.info/coronavirus.

[2] N. Zuraya, "Tiga Dampak Besar Pandemi Covid-19 bagi Ekonomi RI," Republika, 2020. [Online]. Available: https://republika.co.id/berita/qdgt5p383/tiga-dampak-besar-pandemicovid19-bagi-ekonomi-ri. [Accessed: 15-Jul-2020].

[3] Personalfinance.kontan.co.id, "Ini tips agar pelaku UMKM bisa bertahan hadapi krisis akibat pandemi virus corona," Kontan.co.id, 2020. [Online]. Available: https://personalfinance.kontan.co.id/news/ini-tips-agar-pelaku-umkm-bisa-bertahan-hadapikrisis-akibat-pandemi-virus-corona?page $=$.

[4] J. A. Schumpeter, "The Theory of Economic Development," Redvers Opie, Harvard Econ. Stud., vol. 40, p. 20, 1934.

[5] J.-M. Sahut and M. Peris-Ortiz, "Small business, innovation, and entrepreneurship," Small Bus. Econ., vol. 42, no. 4, pp. 663-668, 2014.

[6] D. Miller and P. H. Friesen, "Innovation in conservative and entrepreneurial firms: Two models of strategic momentum,” Strateg. Manag. J., vol. 3, no. 1, pp. 1-25, 1982.

[7] G. T. Lumpkin and G. G. Dess, "Clarifying the entrepreneurial orientation construct and linking it to performance," Acad. Manag. Rev., vol. 21, no. 1, pp. 135-172, 1996.

[8] W. E. Baker and J. M. Sinkula, "The complementary effects of market orientation and entrepreneurial orientation on profitability in small businesses," J. small Bus. Manag., vol. 47, no. 4, pp. 443-464, 2009. 
[9] W. Wu, M. Chang, and C. Chen, "Promoting innovation through the accumulation of intellectual capital, social capital, and entrepreneurial orientation," R\&d Manag., vol. 38, no. 3, pp. 265-277, 2008.

[10] H. M. Campos and F. A. A. Valenzuela, "The relationship between entrepreneurial orientation, time orientation and small business performance: an evidence from Mexico," Rev. Da Micro E Pequena Empres., vol. 7, no. 1, pp. 48-63, 2013.

[11] J. Ejdys, "Entrepreneurial orientation vs. innovativeness of small and medium size enterprises," 2016.

[12] A. Kalkan, Ö. Ç. Bozkurt, and M. Arman, "The impacts of intellectual capital, innovation and organizational strategy on firm performance," Procedia-social Behav. Sci., vol. 150, pp. 700 707, 2014.

[13] H. Wu, J. Chen, and H. Jiao, "Dynamic capabilities as a mediator linking international diversification and innovation performance of firms in an emerging economy," J. Bus. Res., vol. 69, no. 8, pp. 2678-2686, 2016.

[14] P. Newbold, W. L. Carlson, and B. Thorne, Statistics for business and economics. Pearson Boston, MA, 2013.

[15] R. Cantillon, "Essai sur la nature du commerce en general. Institut National d'Etudes Démographiques.” Reprod. facs. de la ed, 1755.

[16] I. C. MacMillan and P. E. Jones, "Designing organizations to compete," J. Bus. Strategy, vol. 4, no. 4 , p. $11,1984$.

[17] C. Y. Woo, "The surprising case for low market share," Harv. Bus. Rev., vol. 60, no. 6, pp. 106114,1982

[18] M. E. Porter and C. Advantage, "Creating and sustaining superior performance," Compet. Advant., vol. 167, pp. 167-206, 1985.

[19] D. Miller and P. H. Friesen, "Organizations: A Quantum View," Relations Ind. Relations, vol. 39, no. 3, pp. 636-637, 1984.

[20] S. L. Hart, "An integrative framework for strategy-making processes," Acad. Manag. Rev., vol. 17, no. 2, pp. 327-351, 1992.

[21] L. J. Bourgeois III, "On the measurement of organizational slack," Acad. Manag. Rev., vol. 6, no. 1 , pp. 29-39, 1981.

[22] J. L. Bower, Managing the Resource Allocation Process. Boston, 1970.

[23] A. H. Pratono, C. W. Tee, D. H. Syahchari, A. T. Nugraha, N. K. N. Mat, and H. Fitri, "The direct effect of entrepreneurial orientation and innovation success on firm performance," Am. J. Econ., vol. 3, no. 1, pp. 1-6, 2013.

[24] S. Suyanto and A. H. Pratono, "The Impact Of Enterpreneurship Orientation, Human Capital And Social Capital On Innovation Success Of Small Firms In East Java," J. Manaj. dan Teknol., vol. 13, no. 2, pp. 117-125, 2014.

[25] J. C. Hayton, "The effect of intellectual capital on entrepreneurial orientation in hightechnology new ventures.," 2003. 